\title{
PROMOTING RHEMA TOURS AND TRAVEL'S HOLYLAND TOURS USING A MARKETING BOOKLET
}

\author{
Puspita, $\mathbf{N}^{1}$, Ibrahim, J. $\mathbf{I}^{2}$ \\ 1,2 English Department, Faculty of Letters, Petra Christian University, Siwalankerto 121-131, Surabaya \\ 60236, East Java, INDONESIA \\ E-mail:m11413004@john.petra.ac.id,jusufib@petra.ac.id
}

\begin{abstract}
Rhema Tours and Travel is a travel agency located in Jalan Jemursari 234A that specializes in Christian pilgrimage trips. It offers tours to Israel, Jordan, Egypt, and Europe. There were only a few people who know about Rhema Tours and Travel. This is probably due to ineffective promotional tools. Rhema Tours and Travel had brochures and company profiles to promote their Holy-land tours. However, those promotional tools are not very effective since they did not highlight the uniqueness of Rhema's Holy Land Tours. Therefore, I made a marketing booklet to serve as an effective promotional tool that can promote Rhema's Holy Land tours to customers by highlighting its uniqueness.
\end{abstract}

Keywords: promotion, promotional tool, marketing booklet

\section{INTRODUCTION}

There are some business communication problems I found in this travel agency. First of all, they have difficulties in organizing their customers' data. In my opinion, this is because they do not have a systematic database of their customers. A database is important to save the data of customers who have ever joined the tour programs so that they can find and contact customers who are prospective to join the next tour programs. At that time, whenever they need to contact customers, they have to find the data manually which is very ineffective and consumes a lot of time. The best solution for the problem I think is to make a systematic database. So, whenever they need the customers' data, they just need to input the keywords and they will find the data they need which is more effective and less time-consuming.

The second problem I found in Rhema Tour and Travel is that the booth officers are not organized very well. They do not have written guidelines and standard of procedures (SOP) for booth officers. On special occasions, they open booths in churches to promote their Holy land tour packages. Because they have no written guidelines, the booth officers sometimes forget what they are told to do. They are also confused how to answer the customers' questions about information that are not stated in the brochures. That is why I think it is better for Rhema Tours and Travel to make written guidelines or SOP for booth officers. They may include, for example, standard of procedures and frequently asked questions and their answers.

The third problem I found during my internship in Rhema Tour and Travel was that only a few people know about this travel agency and its Holy land tour programs. Few people know that this travel agency cooperates with some big churches and famous pastors in Indonesia and specializes in Holy land tour programs. In my opinion, this is due to ineffective promotional tools. They have printed company profiles as their promotional tools. However, the content is no longer relevant since it has not been updated for years. They also distribute brochures and send emails to promote their tour packages. In my opinion, using brochures is not very effective, because each brochure can only contain details of information of one tour program. Customers might want to know the other tour program choices.

I choose the third problem to solve as my Business Communication Final Project, because, in my opinion, the third problem is the most important problem to solve first. It is very important for a travel agency to be well-known. Even though they have very good tour programs, if only a few people know about them, there will be only a few people who join the tour programs. It will be hard for the travel agency to sell their products and services and it could affect their sales. On the other hand, if more people know about this travel agency and its Holy-land tour programs, then more 
people will join the tour programs and the travel agency can gain more profit. Therefore, an effective promotional tool should be made immediately. In order to solve the problem above, I made a marketing booklet for Rhema Tours and Travel.

There are some benefits Rhema Tours and Travel can get from this marketing booklet. First of all, Rhema Tours and Travel can get a promotional tool that can promote their Holy land tour programs effectively to its customers. By reading the marketing booklet, the customers can see what kind of Holy land tour programs this travel agency offers, the facilities they can get, the tourism places usually visited, and many others. Customers can get a clear idea of what this travel agency offers. Hopefully, this marketing booklet can help to increase Rhema Tour and Travel's brand awareness, and customers can have better understanding about this travel agency and its products.

Secondly, this marketing booklet can also be a cost-effective media to promote Rhema Tours and Travel. If Rhema joins a travel exhibition outside Surabaya for example, they do not need to send their representatives to the exhibition. They can just send the marketing booklet and hire someone to distribute them. It will cost them a lot of money, because without marketing booklets, they need to send their representatives to attend the exhibition and pay for their transportation, accommodation, meals, and many others.

Thirdly, the marketing booklet can help to project a strong, professional image of the travel agency to the customers. A well-designed and well-composed marketing booklet can build an image in customers' mind, that this travel agency is professional. Moreover, the marketing booklet will be printed in art papers so it can emphasize the sophisticated image of Rhema Tours and Travel.

Promotional tool, according to Oxford Online Dictionary, is "a device used to publicize or advertise a product, organization, or venture to increase sales or public awareness". There are a lot of kinds of promotional tools. The most widely used promotional tools are promo videos, websites, and marketing booklets. In order to solve Rhema Tours and Travel's promotional problem, I chose to make a marketing booklet.

According to AMA (American Marketing Association), marketing is "the activity, set of institutions, and processes of creating, communicating, delivering, and exchanging offerings that have value for customers, clients, partners, and society at large." Whereas according to Oxford Online Dictionary, booklet is "a small, thin book, with paper covers, typically giving information on a particular subject". So a marketing booklet is a small book that gives information about a company's products in order to promote the products or make people aware of the products.

The reason why I choose to make a marketing booklet than other promotional tools is because a marketing booklet is the most suitable solution for Rhema Tours and Travel's problem. They have brochures and company profiles but they do not contain sufficient information and do not highlight the uniqueness of the Holy Land tours. So, they need a promotional tool that can contain enough information about Holy Land tours and highlight its uniqueness. They also need a promotional tool that can be distributed easily. Therefore, I decided to make a marketing booklet.

There are some considerations why I choose to make a marketing booklet in printed form. First of all, printed media is easier to be read by Rhema's prospective customers, which are mostly 40 years old and above. People of that age usually prefer to read information from printed media than online media. Secondly, printed marketing booklet is easier to be distributed. The customers can keep the booklet and refer it to their relatives for recommendation. Moreover, the marketing booklet will be printed in art papers so it can project the professional image of Rhema Tours and Travel to customers. So, in my opinion, a printed marketing booklet is a better solution for Rhema Tours and Travel.

According to ehow.com and business2community.com, there are some principles we need to pay attention to in making a marketing booklet.

First of all, we should only provide useful, important, and relevant information. We should not provide more information than necessary because it will overwhelm the readers and they will not be interested to read it. We need to sell not to tell. Telling means giving the readers as much information as possible, whereas selling means giving just the right amount of information to persuade the readers to buy the products. Val Adkins stated in his book,Creating Brochures and Booklets, "Do not use more words than you must, but use words that will grab your readers' attention" $(1994$, p.6). He also stated that since the name "booklet" refers to "a small book", there should not be too much information in the booklet (1994, p.4). Therefore, the information in the 
booklet should be appropriately selected to serve the original purpose of booklet effectively, that is to promote the company's products and services.

Secondly, the booklet's layout design should be interesting and helps the customers to read the booklet easily. For example, we can use soft colors, give more space between lines, break the content down into short sections separated with clear headlines, and many others. Visuals can also help to make the booklet looks more interesting. But we need to make sure the visuals we use are relevant with the information in the booklet, high-quality, and attractive. We also need to consider the company's brand in designing the booklet. Company's brand could be emphasized by using the same color or fonts as the company's logo or website.

Thirdly, the content of the booklet should be well-organized. One way to make the booklet more organized is by including a table of content, especially for booklets that contain more than 8 pages. A table of content can help the readers to find the information they need easily. It can also give them an idea about the summary of the booklet. A page of details about the company's products and services is also important to be included in a marketing booklet. It is better to put some graphics in this page to make it more appealing. Then, the contact of the company should also be put in the booklet. We need to make sure the readers know who to contact when they are interested in joining the Holy-land tours. To make it more convenient for the customers, it is better to give them options on how to contact the company. For example, the contact might include not just the address of the office or the phone number, but also email addresses, social accounts, websites, facsimiles, or anything that can help the customers reach the company easily.

\section{METHODS}

First of all, during my internship in Rhema Tours and Travel, I observed how the travel agency worked, and what can be improved for them. So, I found three problems in Rhema Tours and Travel and I chose to solve the third problem that there are only a few people who know about Rhema Tours and Travel. After analyzing the problem, I decided to make a marketing booklet that can promote Rhema's Holy Land tours effectively to customers.

So I started to write the proposal and consulted it with my advisor. I also included the draft content of the booklet in the proposal. I showed the proposal to the owners and the Operational Manager of Rhema Tours and Travel and they accepted the proposal. They gave some suggestions on the content. Then, I revised the booklet's content according to their feedback.

As soon as I finished revising the content, the booklet designer and I started designing the layout of the booklet. I used the color of Rhema's logo, blue and orange as the background color of the booklet to emphasize the company's brand. I also started collecting pictures from internet and from Rhema's DVD of Holy Land tours to be put in the booklet. After finishing the first draft of the booklet, including the content, design, and layout, I showed it to the Operational Manager for feedback. The manager gave some more feedbacks on the layout and design. Then, I revised the layout and design based on the manager's feedback. As soon as I finished revising the layout and design, I showed the booklet's final draft to the Manager. As the manager approved the final version of the booklet, I started printing the marketing booklets.

\section{FINDINGS AND DISCUSSIONS}

The product that I made for my BCFP is a marketing booklet for Rhema Tours and Travel. The purpose of this marketing booklet is to make people aware of Rhema Tours and Travel and to promote its products and services, especially Holy-land tours. Therefore, in this booklet, I have included the uniqueness of Rhema's Holy-land tours. This booklet consists of five sections; those are the table of content, the company overview (About Rhema Tours and Travel), the description of products and services, the description of Holy-land tours, and the gallery.

The target market of Rhema's Holy-land tour is middle-upper class people around 40 years old and above. Therefore, this booklet is aimed for this group of people. However, this marketing booklet can also be used by Rhema's employees as a mean to improve their product knowledge and also by other travel agencies or institutions which are interested in cooperating with Rhema Tours and Travel.

I made two versions of the booklet, Indonesian version and English version. The reason I made two versions of the booklet is that each version can serve different purposes. The majority of 
Rhema's Holy-land tour participants are Indonesian with 40 years old of age and above. Some people in that age group might not understand English. Therefore, I made it in Indonesian so that they can understand the information in the booklet. Besides Indonesia, some Rhema's customers also come from other countries such as Malaysia, Singapore, Thailand, and United States of America. For those customers, the English version of the booklet would be a more appropriate choice. Besides, by reading a booklet in English, the customers will get an image that Rhema Tours and Travel is a professional and experienced travel agency.

Throughout the booklet, I use blue and orange as the background colors since they are the colors of Rhema Tours and Travel's logo. Referring to the second principle, using the color of the company's logo in the booklet can emphasize the company's brand. For the text, I mostly use white and black for contrast, so that it is easier to be read.

In the front cover of the booklet, I put the pictures of Jerusalem. I chose those particular pictures because they were the iconic pictures of Jerusalem. So, only by looking at the pictures, the customers can tell that this booklet gives information about Holy-land tours. I also put some pictures of tourist attractions in Egypt, Israel, and Jordan to make it more attractive. I put the pictures of Garden Tomb, The Western Tunnel, The Giza Pyramid, Mount Hermon, Lake Galilee, and Mount Nebo. I chose those particular tourism places pictures to be put in the front cover of the booklet, because they are the highlight of the tours. They are the most well-known tourism places and they have historical relations with the Bible. The title of the booklet is To Holyland with Rhema Tours and Travel. I want the readers to know that this booklet is about tours to Holy Land only by reading the title and looking at the pictures. For the "Holyland" word, I use gold color, to represent the color of lights in Jerusalem, as seen in the picture. For the word "Rhema Tours and Travel", I use Rhema Tours and Travel's logo to emphasize the company's brand. In designing the cover of the booklet, I applied the second principle to make a good marketing booklet that is to give interesting visuals to attract the readers.

In the back side of the front cover, I stated that this booklet is made by me, a student of English for Business Communication, Petra Christian University in December 2016 as my final project. I choose the color orange as the background of this page to be consistent with the theme of the booklet.

In the next page is the table of content. In the table of content, I put the list of the booklet's sections, which are About Rhema Tours and Travel, Products and Services, Holy Land Tours and Rhema's Gallery. I put the table of content in the booklet so that the readers can get an idea about what information the booklet contains and how the booklet is organized. I also put the pages to make it easier for the readers to find the information they need. Referring to the third principle, to make a good marketing booklet, information should be organized well to make it easy for the readers.

After the table of content is a page about the company overview, "About Rhema Tours and Travel". In this page, I put a brief introduction about the travel agency, for example when the travel agency was established, who the owners are, and what tours they specialize in. In the second paragraph, I explain the uniqueness of Rhema's Holy-land tours. So that only by reading this paragraph, the readers can get the idea that Rhema Tours and Travel does not only arrange trips to Holy-land but it also provides tour participants with spiritual services. In the next page, I put the profile of Rhema Tours and Travel's staff. I put their pictures and names in this section. I want the readers to know that Rhema's staff are experienced and professional.

The next section is Products and Services. In this section, I put the list of all products and services Rhema Tours and Travel offers. The purpose of this section is that, even though throughout the booklet I emphasize the uniqueness of Rhema Tours and Travel's Holy Land tours, I also would like the readers to know that Rhema Tours and Travel also serves other tours beside Holy Land Tours. They also serve travel-document handling, airline tickets, hotel room reservations, study tours, and other tour programs. In this section, I put some pictures of Rhema's study tour programs, which I got from Rhema's DVD. The purpose of these pictures is to assure the readers that Rhema Tours and Travel is experienced in conducting this kind of tour programs. But, I also put some pictures of the tourism places usually visited during the tours, like the Eiffel Tower in Paris, Colosseum in Rome, Wat Phra Kew in Bangkok and windmills in Amsterdam which I got from Google. The purpose of these pictures is to rouse the readers' interest to visit those places. I could 
not use the pictures from Rhema's DVD because the resolution of the pictures is not very good and therefore it is not very effective to attract the readers' interest.

The next section is about the Holy Land Tours. In the first page of this section I put the list of the uniqueness of Rhema Tours and Travel's Holy Land tours. I wrote that Rhema Tours and Travel does not only provide tours to Holy Land, but it also provides its participants with spiritual services like spiritual leaders, Holy Communion service, baptism and rededication in Jordan River, and marriage rededication in Kana. In this section, I put some pictures from Rhema's DVD to ensure the readers. For example, I put the picture of one of Rhema's Holy Land group tours with Ps. Phillip Mantofa, the picture of Garden Tomb, the photograph of a person being baptized, and the photograph of a marriage rededication in Kana. All of the pictures I used in this section are from Rhema's DVD. The purpose of these pictures is to show the credibility of Rhema Tours and Travel. By looking at these pictures, the readers can be assured that Rhema does not only provide tours to Holy Land but it also provides its participants with spiritual services.

On the next page, I write the details of the first type of Holy-land tours, Holy-land Tour Regular 9\&12 Days. In this section, I put the pictures of the tourism places visited during the tours and the description of the places. The purpose of this section is to attract the readers to visit those places. That is why; I prefer to use pictures from the internet instead of Rhema's own pictures. Since the resolution of Rhema's pictures is not very good, the pictures do not look very attractive. On the other hand, the pictures from the internet look more appealing because of its good resolution. I choose these places to be put in the booklet because they are the highlight of the tours. These places have their own background stories in the Bible, which make them the most attractive places to visit for most tour participants. I organized the places based on their countries of location to make it easier for the readers. For example, in Egypt, I put Giza pyramid and Mount Hermon, in Israel I put Mount Sinai, Armageddon Valley, The Western Wall and Tunnel, Nativity Church, and Via Dolorosa. In Jordan, I put Mount Nebo. I write each paragraph in a white box to make it easier to be read. I try to limit the length of sentences as well so that it does not overwhelm the readers. In writing the content, I use the first principle of a good marketing booklet that is to provide only important information. In designing the layout, I applied the second principle of a good booklet, which is to arrange the layout and give interesting visuals to encourage the customers to keep reading the booklet.

The second type of Rhema's Holy Land Tour is Holy Land Europe Tours. In this section, I do not organize the places based on the countries. The places visited here is the additional places visited besides the places in Holy Land Tour Regular. Like the previous section, I put the name of the places, the descriptions, and the pictures.

The third type of Rhema's Holy Land Tour is Holy Land and Minor Asia Tour. In this section, I put the countries visited during the tours as well as the names and the pictures of the tourism places. Some of the places I chose are Hagia Sophia, which was one of the biggest churches in the world and Bosphorus Strait, the strait which divides Asian and European continent.

In the next section, I stated the starting price of Holy-land tours. I also explain what facilities are included in that price. This section is important because the customers need to know the estimated amount of money they have to prepare if they want to join Rhema's Holy-land tours and what facilities are included in the price.

The last section of the booklet is Rhema's Gallery. In Rhema's Gallery, I put the group tours pictures from Rhema's DVD. I choose the pictures with the best quality and the pictures with most tour participants. The pictures in this section serve as proofs that Rhema Tours and Travel is a real professional travel agency and experienced in conducting various types of Holy Land Tours.

In the last page of the booklet, I put the contact information of the travel agency. I put the address of Rhema Tours and Travel's office, the phone and fax numbers, the Facebook, Twitter and Instagram account, as well as email address and Blackberry Pin. Based on the third principle of a good marketing booklet, contact information is important to make it easier for the reader to contact the travel agency when they want to ask further information.

\section{CONCLUSION AND SUGGESTIONS}

I did my internship in Rhema Tours and Travel. This travel agency specializes in Holy-land Tours. It has some problems, one of which is, there is only a few people who know about Rhema 
Tours and Travel. This problem, I believe, is due to ineffective promotional tools. This travel agency uses brochures and websites, but those promotional tools cannot really show the uniqueness of Rhema Tours' and Travel Holy-land tours. Therefore, I chose to make a marketing booklet for Rhema Tours and Travel. Besides providing information about Rhema's products and services, this marketing booklet highlights the uniqueness of the Holy-land tours.

There are some benefits the travel agency can get from this marketing booklet. First of all, the travel agency can get an effective promotional tool that can introduce Rhema Tours and Travel to potential customers and highlight its uniqueness. Secondly, it is a cost-efficient media to promote Rhema Tours and Travel. When there is an exhibition, Rhema does not need to send representatives, they can just simply send the marketing booklet and ask someone to distribute them. Thirdly, it can project a professional image of Rhema Tours and Travel since it is designed attractively, composed well, and printed in art papers.

My suggestion for the next EBC students who want to do Business Communication Final Project is that it is better to start discussing about the plan to do BCFP in the company during the internship period, to make sure the students can do the project in the company. If not, there is a possibility the students cannot do the project in the company where they do the internship, and they would have to find another company.

\section{REFERENCES}

Adkins, Val. (1994). Creating Brochures and Booklets. North Light Books; 1 edition (March 1994)

Booklet [Def. 1]. (n. d.) In Oxford Dictionaries Online, Retrieved from https://en.oxforddictionaries.com/definition/booklet

Davidson,K. (2008, January 7). How to Create a Marketing Booklet. Retrieved from http://www.ehow.com/how_2172922_marketing-booklet.html

Definition of Marketing. (2013, July). Retrieved from https://www.ama.org/AboutAMA/Pages/Definition-of-Marketing

Hornor, T. (2012). Tips for Better Sales Booklets. Retrieved from http:// www.business2community.com/marketing/tips-for-better-sales-booklets-0274390\#R 1uptM43GLZdf5S2.99

Marketing [Def. 1]. (n. d.) In Merriam-Webster for English Language Learners, Retrieved from http://www.merriam-webster.com/dictionary/marketing

Promotion [Def.1]. (n. d.) In Business Dictionary, Retrieved from $\mathrm{http}: / / \mathrm{www} \cdot$ businessdictionary.com/definition/promotion.html

Promotion [Def. 2]. (n. d.) In Oxford Dictionaries Online, Retrieved from https://en.oxforddictionaries.com/definition/promotion

Tool [Def. 1]. (n. d.) In Oxford Dictionaries Online, Retrieved from https://en.oxforddictionaries.com/definition/tool 